Article

\title{
Immigration Federalism as Ideology: Lessons from the States
}

\author{
Lina Newton \\ Political Science Department, Hunter College, CUNY, 695 Park Avenue, New York, NY 10065, USA; \\ E-Mail: lnewton@hunter.cuny.edu; Tel.: +1-212-772-5500; Fax: +1-212-650-3669 \\ Academic Editor: Ingrid V. Eagly \\ Received: 14 October 2015 / Accepted: 14 November 2015 / Published: 25 November 2015
}

\begin{abstract}
Over the last decade states passed hundreds of immigration bills covering a range of policy areas. This article considers the recent state legislative surge against scholarly treatments of immigration federalism, and identifies the symbolic politics in state lawmaking. The analysis combines a historical treatment of key court decisions that delineated boundaries of state and federal immigration roles with a legislative analysis of over 2200 immigration bills passed between 2006 and 2013, to identify the numerous ways in which national immigration policy shapes state measures. It argues that recent laws must be considered against symbolic federalism which privileges state sovereignty and justifies social policy devolution by advancing frames of intergovernmental conflict, state-level policy pragmatism, and federal ineffectiveness.
\end{abstract}

Keywords: immigration federalism; state immigration laws; symbolic politics

\section{Introduction}

On 8 November 1994, voters in California overwhelmingly approved a ballot measure, Proposition 187 , which denied a variety of public services — including public schooling and medical care - to those whom public servants "suspected" of being unauthorized immigrants. Polling conducted just in advance of the state's general election showed a public well-aware that even if passed, Proposition 187 would end up in court. The measure's enforceability did not seem to matter to the thirty-seven percent of respondents who claimed that their goal in voting for the measure was to "send a message that something has to be done about illegal immigration" $[1,2]$.

By 1997, a federal district court ruled California's measure unconstitutional on the grounds of preemption, meaning that the state initiative created an immigration enforcement scheme that interfered 
with the federal government's sole authority over immigration regulation and enforcement ${ }^{1}$. This outcome, however, did not dampen the desire of states to pass similar laws. In 2004, Arizona voters passed Proposition 200 which was modeled on California's failed initiative. Colorado's own efforts in 2006 ran afoul of the state's electoral laws, but in 2006, the Georgia legislature passed the Georgia Security and Immigration Compliance Act (SB 529), a piece of omnibus legislation ${ }^{2}$ that covered law enforcement, identification requirements, employment and human trafficking in addition to other areas associated with immigration and immigrants. Such copycatting persists. After Arizona passed SB 1070 in 2010, Alabama, Indiana Georgia, Utah and South Carolina introduced and passed similar enforcement bills shortly afterwards. State laws designed to prevent from immigrants from voting are also similar to one another. By 2013 an additional 16 state omnibus immigration bills similar to Georgia's SB 529 were on the books. More recently, the states of Maryland, Texas, New York and others extended in-state tuition for public colleges and universities to undocumented immigrant students, and did so despite a federal statute designed to limit such access. Collectively, these laws have raised the stakes for the national government, forcing inter-systemic conflicts and amplifying a sense that the national government is absent from an immigration crisis.

When federal immigration reform efforts in Congress failed in 2006 and again in 2007, statehouses across the country seemed prepared to step in: by the end of 2007 , each of the fifty state legislatures contributed to the passage of hundreds of bills addressing immigration and immigrants [3]. In successive years, the total would climb: by end of 2014, states had passed over 3000 immigration-related bills [4]. Regardless of whether states strike accommodating or restrictive postures, however, it would seem that states, having long ago ceded power to the national government on these matters, are ready to take it back. Neither a century old doctrine of national supremacy over immigration policy and its enforcement, nor the promise of costly court battles have deterred them.

Federalism simultaneously allows for the blurring of jurisdictional boundaries and state independence from Washington DC. The debate in the growing literature on immigration federalism (the subnational development of regulatory and settlement policies) [5], divides over whether states are operating within their historical and constitutionally mandated role as demi-sovereigns in areas of immigrant settlement [6-8], or whether state activism poses a threat to nationally-enforced civil rights and individual rights derived primarily from the fourteenth amendment's equal protection clause [9-11]. As a mode of policy delivery, however, federalism has changed in complex ways since the emergence of national supremacy on immigration matters. For example, the national government became the primary protector of civil rights after longtime resistance from the states [12]. In other policy areas, the national government's authority has coincided with vertical integration of policy delivery. The national security regime demands cooperation from state and local enforcement agencies areas where intergovernmental responsibilities were once distinctive [13]; immigration enforcement agencies, a key component now of

\footnotetext{
LULAC v. Wilson 1997.

2 Omnibus bills package separate (and sometimes unrelated) measures into one bill which is then brought up in a legislature for a simple "yes" or "no" vote. In this case, state omnibus bills would combine immigration-related topics such as immigration law enforcement, employment eligibility enforcement, anti-human trafficking and appropriations to various agencies including those providing immigrant services.
} 
national security, regularly make use of state and local agencies to expand their reach and to carry out national initiatives $[14,15]$.

Furthermore, the frequency and extent of recent state lawmaking, as well as utilization of statehouses and court battles to register discontent with the national government, show a political movement at work. Legal and social science scholarship attending to this revival of subnational lawmaking considers a broad range of political and structural factors responsible for the surge. Both approaches attend to the instrumental aspects of federalism - as governance structure and with layered modes of policy delivery. What is less often discussed, however, are the expressive aspects of state-level lawmaking - specifically the manner in which federalism operates as a frame of reference that privileges the role of states in policy making, and locates the root of intractable social issues in the national government.

This ideological or symbolic federalism advances states as the original guardians of local intereststhese are, after all, the entities the founders maintained because the smaller domains allowed for tailored policy approaches sensitive to local needs and more responsive to the people ([16], pp. 4-5). Over time, federalism has offered the political rationale for state sovereignty; progressive and conservative interests have appealed to state authority in staking and justifying their positions on a range of policy issues ([16], p. 9). Such appeals to state sovereignty have justified state resistance to civil rights for racial, ethnic, gender, and sexual minorities; state authority also determines rights of access to the welfare state, and is central in debates over budgetary and fiscal responsibilities.

Given that claims about privileges and entitlements, individual and group rights, and fiscal responsibility all collide in immigration politics, it is about time to attend to the expressive aspects of state involvement in immigration matters.

The argument unfolds as follows: first it advances the importance of federalism and immigration federalism specifically, as operating within ideological frames that highlight conflicts between states and the national government. The second part looks at the ascendance of the national regulatory scheme at the expense of states and identifies the transformation in state laws from regulation of immigrant entry to regulation then restriction of immigrant access to public services, to participation in immigration law enforcement. The third part explores the recent wave of state-level laws: it offers an analysis of state bills passed between 2006 and 2013 to reveal areas of substantive and symbolic conflict with federal laws. Part four offers an assessment of the symbolic politics of immigration federalism that focuses on intergovernmental conflict as well as the curative potential for immigration federalism in absence of national leadership or consensus on the issue.

\section{The Instrumental and Expressive Faces of Immigration Federalism}

To begin, it is necessary to consider the possible roles that states can play in immigration politics as conduits for national policy imperatives and as legislative bodies that amass local interests and responses to conditions at the ground level. Social science scholarship has identified conditions within states that explain variation in policy approaches. In the case of state forays into direct and indirect enforcement and regulation, some view these laws as products of racial divisions and anxieties, where conservative political ideologies correspond with restrictive measures [17-19]. In the case of Arizona-presently the state taking the most punitive stance against immigrants - scholars have deftly covered the genesis of that state's particular brand of immigration confrontation at the granular level. Arizona's recent history 
with the vigilante Minuteman Project, Maricopa county Sheriff Joe Arpaio's ongoing civil rights catastrophes, and efforts to impose Anglo-conformity on public education curricula, all reflect conservative policy responses to sizable demographic shifts, societal transformation and racial and economic insecurity [18,20].

States, however, also serve as alternative venues for nationally-active interests faced with stalemate in Congress. The press, for example, has been following the state by state actions of Kris Kobach (currently the Attorney General of Kansas) who drafted Arizona's SB 1070 and Alabama's SB 56, and has been tapped to do the same for other states as well. He and his financial backers have publicly announced a statehouse-by-statehouse strategy to achieve immigration control via state measures that create an inhospitable climate for unauthorized immigrants and encourage "self-deportation" [21-24]. Likewise, in their work on advocacy coalitions, political scientists Gary Reich and Jay Barth tracked the same interest groups operating in five Republican statehouses pushing for restrictive laws [25]. This is not mere diffusion as some have argued [26], but a coordinated strategy put forward by national interest groups and policy entrepreneurs to venue-shop downwards.

States serve as interlocutors for ground-level pressures and national immigration interests. However, rather than be merely sandwiched in the "middle-tier", states also serve as agents in the debate particularly when they assert their sovereignty. Peter Spiro has argued that states provide a policy "steam-valve" [27] that reduces pressure on a national government to seek consensus on a divisive and intractable policy issue. The neutrality implied in that analogy, however, discounts the manner in which some states have devised clear stances as "open" or "hostile" to their resident unauthorized populations. In this respect, states increasingly function as pressure cookers for the debate over whether the nation should embrace its undocumented immigrants. In the most extreme cases, like California in 1994 and Arizona in 2010, policy making occurs with expectation of court battles with the federal government where the generation of such conflict is understood both in the public as well as the leadership to "send a message" about that state's position on the issue [2,28,29].

Over the last decade, state legislative activity has not dispersed pressure in immigration politics, it has raised it: there are now fifty potential stages for state-federal showdowns on the issue. The fault lines of federal-state conflicts take shape depending on which aspect of immigration a statehouse opts to resolve. Whether states pursue more inclusive or more restrictive policies, a common grievance is the lack of congressional action to cope with immigration and its associated issues. The frustration voiced at the state level and covered in news sources depicts states burdened with fiscal and governance responsibilities in the absence of congressional leadership and comprehensive federal-level reforms [29-37].

A distinctive conflict frame arises over enforcement: states opting to strengthen enforcement roles cite limited or absent of federal enforcement as the source of their unauthorized immigrant populations. However, what makes this conflict distinctive is that while federal enforcement is portrayed as deficient, states engage cooperatively with federal agencies in apprehending irregular immigrants, and in policing and sanctioning employers of unauthorized workers [14,38]. State attempts to assert authority over immigration also address a debate over whether immigrants add to the economic good or cost more than they contribute. Viewed from the perspective of balanced budget conservativism [39], such laws represent resistance to a national program seen to enable undeserving populations. What appears at first a novel effort among states to govern the field of immigration, is actually the next step in the conservative response to the national government's role in the rights revolution of the 1950s-1960s. 
This is not the first attempt to see state-level immigration policy as reflecting the symbolic politics of anti-Washington, anti-welfare state conservativism. In a 1996 article, Kitty Calavita offered an analysis of California's Proposition 187 (1994) as a condensation symbol for economic uncertainty, socio-economic transformation, and xenophobic nationalism. Calavita's analysis placed the punitive ballot measure in the context of past restrictionist policies that coincided with economic recession, worker anxieties, and linked these to vast structural transformations wrought by globalization. That context, combined with balanced budget conservatism, ensured the popularity of a law designed to punish unauthorized immigrants [40]. More significantly to Calavita's argument, these expressive (or symbolic) elements of 187 proved more important than the instrumental, or curative claims of the law. California voters, as polls leading up to the general election showed, understood that the law might never be implemented and would result in costly court battles; these likely outcomes were secondary to voters sensing an opportunity to "send a message" to Washington.

The analysis that follows owes its conceptualization to Calavita's study of Proposition 187, and also starts with Murray Edelman's assumption that lawmaking — as all political activity — has instrumental and expressive facets that are equally deserving of inquiry ([41], p. 12). However, rather than focus on laws as reflective of public opinion at the state level, this examination of instrumental and expressive facets of state laws by placing this activity within a legal doctrine and policy regime that rests on national supremacy. It regards the recent and unprecedented surge in state lawmaking as instrumental in that most of these are policy efforts designed to solve immigration-related problems, and have emerged in response to political impasse at the national level. Additionally, it attends to the expressive aspects of immigration lawmaking at the national level by examining intergovernmental conflict generated by these state efforts. While often, and for good reason, studies of state-federal conflict will focus on restrictive measures like Proposition 187 or SB 1070, this analysis seeks to broaden the scope of inquiry into immigration federalism by also considering laws that accommodate unauthorized immigrants.

\section{Immigration and Federalism in the Courts}

As central as immigration has been to the development and identity of the United States as a nation, immigration has long challenged the national government to regulate flows, ensure security, economic demands, and manage claims-making. Immigration has also long exposed rifts within the federal system, where the Court's consistent endorsement of national supremacy in matters relating to the entry and exit of foreigners often conflicts with the regional and local desire for greater flexibility from national policy. This section identifies the jurisdictional conflicts that evolved into a legal doctrine of national supremacy at cost to state power. The goal is to identify the historical shift in the balance of regulatory powers to the national government that occurred in the Supreme Court, and to outline the constraints within which states continue to operate. The analysis provides a backdrop that helps explain why current jurisdictional clashes instigated by states are significant focusing events more so for their symbolic stance against the national government than as actions of state sovereignty.

\section{States, Immigration and Consolidation of a National Regime}

We usually characterize the history of American federalism as following a path that moves from state supremacy at the ratification of the Constitution, to co-governance within well-delineated spheres during 
the era of "dual-federalism", to the present system in which the national government is supreme and states, while retaining authority, operate with little autonomy from the federal government. Accordingly, states once designed their own immigration policies, and the shift towards national supremacy was gradual but relatively unabated once begun. The demands of immigration regulation required early development of an expansive national administrative and regulatory enforcement apparatus. Delineation of who was and was not admissible meant early articulation of a nation-centric citizenship [42,43]. Moreover, while state immigration activism has been a feature of this policy area since the nation's inception [44], once the Court was asked to respond to possible jurisdictional overreach, it has acted decisively and, for over a century, consistently in favor of the federal government's exclusive right to design, develop and enforce such policies ${ }^{3}$.

At the nation's founding, states were in charge of immigration regulation and several took steps to bar undesirable foreigners. State laws and some state constitutions defined classes of excludable immigrants such as "convicts and paupers", the "diseased", slaves and free blacks whose importation and migration were controlled in accordance with the status of slaveholding and free [44]. In the absence of centralized immigration administration, port cities processed newcomers, developed immigrant registries and provided health inspections. State and municipal officials designed revenue-raising schemes to cover the putative costs of running and maintaining ports. As insurance against admission of paupers, criminals, "idiots," prostitutes, and the like, state officials required bonds from ship owners and/or the collection of head taxes.

Immigrant exclusion, however, was not the only state concern. The following passage from John Higham's Strangers in the Land (1969) shows states competing to lure immigrants to their lands:

The demand for immigrants was most widespread and intense outside the densely populated states of the Northeast; in the West and South, virtually every state appointed agents or boards of immigration to lure new settlers from overseas. Michigan began the practice in 1845. By the end of the Civil War the northwestern states were competing with each other for Europeans to people their vacant lands and develop their economies. The South joined in, hoping to divert part of the current in its direction in order to restore shattered commonwealths and replace emancipated Negroes. In the 1860's and 1870's, at least twenty-five out of thirty-eight states took official action to promote immigration. South Carolina, in its desperation, added the inducement of a five-year tax exemption on all real estate bought by immigrants ([45], pp. 17-18).

These state-led initiatives, though, occurred alongside ascendance of the national government and the centralization of policies of exclusion, administration, and revenue collection.

The decades immediately following the ratification of the Constitution were ones of robust state governance and limited national government. The Constitution's framers were unclear in assigning responsibilities across the federal system, and as a result, immigration was only one matter that prompted intergovernmental clashes [16]. Early jurisdictional conflicts over immigration involved questions of regulation of commerce, and were arguably as significant to the ascendance of the national government as more commonly known early cases like Gibbons v. Ogden or McCulloch v. Maryland. In The Passenger Cases [46] a fractious court determined that portions of New York and Massachusetts state

3 For more extensive accounting and related case law see [9] and [12]. 
laws applying a per-head tax on foreign ship masters were unconstitutional because their implementation interfered with congressional power granted under the Commerce Clause. What is less clear from the three different opinions issued in this case was whether immigration of free people amounted to "commerce". Also unsettled was whether, in the complete absence of congressional law on a matter, states must still defer to federal power, or whether states could articulate their interests until Congress took steps to legislate in that area.

It wasn't until decisions in Henderson v. City of New York (1875) and Chy Lung v. Freeman (1875), that the Court elaborated on the constitutional bases of federal exclusivity and defined the interests served in maintaining that exclusivity of immigration control. At issue in Henderson were similar statutes in Louisiana and New York that required collection and payment of a head tax from foreign ships prior to disembarking. In outlining the decision against state-mandated ship taxes, Justice Samuel Miller stated:

Though it be conceded that there is a class of legislation which may affect commerce, both with foreign nations and between the states, in regard to which the laws of the states may be valid in the absence of action under the authority of Congress on the same subjects, this can have no reference to matters which are in their nature national or which admit of a uniform system or plan of regulation ([47], p. 260).

In short, even in the absence of specific congressional laws, state activities that might impinge on Congress's constitutional authority over commerce and intergovernmental relations superseded state interests.

Chy Lung involved twenty two Chinese women imprisoned in San Francisco when the ship's captain refused to pay bonds for them. Here, the California statute under scrutiny targeted potentially burdensome immigrants for bonds instead of relying on a universally applied head tax (as was the case in Henderson). California's elaborate regulations endowed its Commissioner of Immigration with the power to board a ship, unilaterally determine the excludability of individual immigrants, demand indemnity for those he deemed might become public charges, and walk away with a percentage of the fees collected. In this instance, the commissioner determined that the detainees were "lewd and debauched women". The Court was united in its decision against California, which Justice Samuel Miller criticized as having produced

... a statute...framed, to place in the hands of a single man the power to prevent entirely vessels engaged in a foreign trade, say with China, from carrying passengers, or to compel them to submit to systematic extortion of the grossest kind ([48], p. 278).

In his opinion, Miller further described California's overreach as potentially detrimental to U.S. foreign relations, and therefore out of line with constitutional powers of Congress and the Executive ${ }^{4}$.

The post-Reconstruction incarnation of the United States as a unified entity with a territorially-defined people, would, in turn, find its expression in a host of new immigration regulations designed to admit immigrants in line with evolving and ascriptive citizen ideals based on race, class, and gender [49-51]. Congress soon erected its own public charge laws, and criteria for inadmissible immigrants replicated those originally articulated at the state level. Regional anti-Chinese fervor found a national stage when

4 Justice Miller rejected the revenue-raising rationale behind the since the money was not used specifically for immigrant care. 
California's sizable delegation in Congress eventually influenced the passage of the 1882 Chinese Exclusion Act ([52], pp. 105-7). A national immigration monitoring system required the deployment of a national administrative and enforcement regime. The growing power and centralization of the national government in this area, in turn, benefitted from the support of successive court decisions that further buttressed national jurisdictional claims in place of those of the states.

In the Chinese Exclusion Cases the Court established the plenary power doctrine, ruling that congressional authority is virtually absolute in defining which standards and rules applied for admission, deportation or removal of $[53,54]$. The decision strengthened earlier rulings citing the constitutional sources of national supremacy seen in Henderson and Chy Lung. It privileged Congress and the Executive in the design and execution of immigration laws with virtually no opening for judicial review. Eventually, quantitative restrictions 1920s quota systems would expand the national apparatus required to regulate immigrant admissions.

By contrast, Congress never articulated a uniform immigrant policy. The years 1910-1924 (also years of highest immigration levels), did, however, provide the context for an Americanization movement. Leaders at all levels of government, social and educational reformers all championed programs to encourage cultural and linguistic assimilation. Although federal funds existed for agencies and organizations that promoted middle class Anglo conformity and conservative nationalism, there was no unifying national policy, sole national agency, or even national official in charge of the effort. Congress made Americanization official concurrent with the passage of the 1924 National Quotas Act. Still, even in the field of education where, as vehicles of assimilation, schools were expected to teach English and civic values, program delivery was left to state and local agencies and organizations with programs already in place [55].

Instead, the states shaped possible paths for immigrant integration within the national administration of entry and removal. With the consolidation of power and relative ascendance of the American nation, state interest in immigration governance remained, though the role of states was now limited. A solid doctrine of national supremacy was in place by the time Congress dismantled National Origins first in 1952, and then again with the ground-breaking 1965 Immigration and Nationality Act, though states still provided for the day-to-day welfare of all those residing in their domains. Jurisdictional fights occurred when Congress had not occupied the field ${ }^{5}$. The absence of national direction was also the source of dispute in DeCanas v. Bica [57]. In this case, a California state law prohibited the knowing employment of unauthorized immigrants at a time when Congress did not. The case arrived in the Supreme Court after the California Appeals Court deemed the state law unconstitutional on preemption grounds. The Supreme Court reversed that ruling, reasoning that just because a state law indirectly or directly affected immigrants did not mean such a law implied state regulation of immigration, and that states' general right to govern the employment relationship extended to unauthorized immigrants. Thus, the ruling

5 In Hines v. Davidowitz (1941), Pennsylvania's Alien Registration Act of 1939 preceded Congress's passage of the Alien Registration Act of 1940. The Pennsylvania Law was enjoined by 3 district judges who claimed the state law both infringed on congressional powers and also denied equal protection to aliens under section 16 of the Civil Rights Act of 1870. The Supreme Court concurred, with Justice Hugo Black arguing that implementation of the Pennsylvania law would create an obstacle to congressional objectives [56]. 
upheld the state law, but it also specified the rules of preemption that would, in turn, inform future state immigration and immigrant laws.

However, as state electorates fought national ascendancy in civil rights protections (the state's rights movement), redistributive social policies (the tax revolts of the 1970s and early 1980s), a new front would emerge among states that used policy to divide the deserving population of taxpayers and citizens from poor and minority residents believed to drain public resources [58]. Immigrant populations - once targeted by state policies for depressing wages and work conditions, criminality, and non-assimilability, increasingly became targets of state laws and voter initiatives that pursue redress for unauthorized immigrants as fiscal burdens. Compared to their position on state efforts to regulated entry and exit, the courts were less consistent on public benefits restrictions: conflicts over the permissibility of state constriction of benefits for immigrants were sometimes ruled unconstitutional $[57,59,60]$. Decisions turned on whether such state laws fell into the category of immigration regulation, or whether they involved violations of the equal protection clause. But, some decisions were critical to protecting the states' authority, particularly in the area of employment [57,61] when it was deemed clearer which state interests these laws served, and that implementation did not infringe upon national powers.

State immigration policies and the jurisdictional conflicts ignited by such measures provide insights into whether states are expected to operate in tandem with the national government, maintain spheres of sovereignty within a structure determined by the national government, or have space to operate independently. Even this brief overview however, illustrates the problem with assuming a clear distinction exists between immigration policy and immigrant policy; the Court itself has not ruled in a manner that confirms such boundaries [62]. Underlying all of these battles is a more fundamental divide over the national responsibility to ensure security, to meet economic demands, and to manage claims-making - all of which have been complicated by co-existing trends: the devolution of social policy delivery from the national government to the states and the integration of law enforcement agencies for the purposes of national security and immigration enforcement. Thus while state-federal clashes over immigration are a longstanding feature of this policy area, more recent state efforts to control, expel or accommodate their immigrant populations must be considered in light of these significant changes to national policy designs that positioned states as arbiters of claims-making, and how, in turn, states have emerged as the sites of anti-Washington revolt.

\section{Immigration Federalism in the Contemporary Era}

This section explores the nature and content of state laws passed during the legislative years of 2006 through 2013. The intensity of state activity is unprecedented in the modern immigration era: all fifty states have contributed to the passage of thousands of laws and resolutions that target immigrants, their employers, as well as agencies that serve them. The analysis also compares state laws to the national policy context, and identifies patterns of cooperation in state-federal policies, and then focuses on areas of state-federal conflict.

The legislative data are from a database the author compiled from the National Conference of State Legislatures (NCSL) Immigrant Policy Project [4]. The NCSL annual reports date back to 2005; the database compiled for project covers eight years, 2006-2013, and includes 2257 actions: 851 resolutions 
and 1406 laws. Seventy of the bills ( 3 percent) that passed through the statehouses were vetoed (in whole or in part) by governors.

The NCSL annual compilations include brief description of bill contents, and a searchable database with links to some bill texts. The contents range from extensive policy measures ensuring state healthcare to undocumented immigrants (in the years prior to the Affordable Care Act), to bills that made minor changes such as re-naming existing state task forces. Additional information about bills came from state news sources in LexisNexis, as well as more focused policy reports from other non-governmental organizations tracking state laws, namely the National Immigration Law Center (NILC), the American Immigration Lawyers Association (AILA), and the American Civil Liberties Union (ACLU). Although these latter organizations are involved in immigrant rights advocacy (as opposed to the NCSL, which views itself as a bipartisan research and informational clearinghouse), their websites provide up-to-date news on litigation, court decisions, policy implementation and additional legislative actions that may not appear in news coverage.

The NCSL reports also arranged policies by type of output (law or resolution) and classified each according to policy area. These categories provided the initial organization, but analysis of content of the "miscellaneous/private" bill category produced other types added for the analysis. For example, the category "Budgets/Appropriations" first appeared in 2009, but such bills were labeled "miscellaneous" in 2006-2008. Bills were re-labeled if their contents indicated they belonged in other categories.

\subsection{State Lawmaking: An Overview}

State activity is largely perceived to coincide with failed congressional attempts to overhaul federal policy. Figure 1 depicts annual levels of activity both in terms of bills introduced in state legislatures, and those passed.

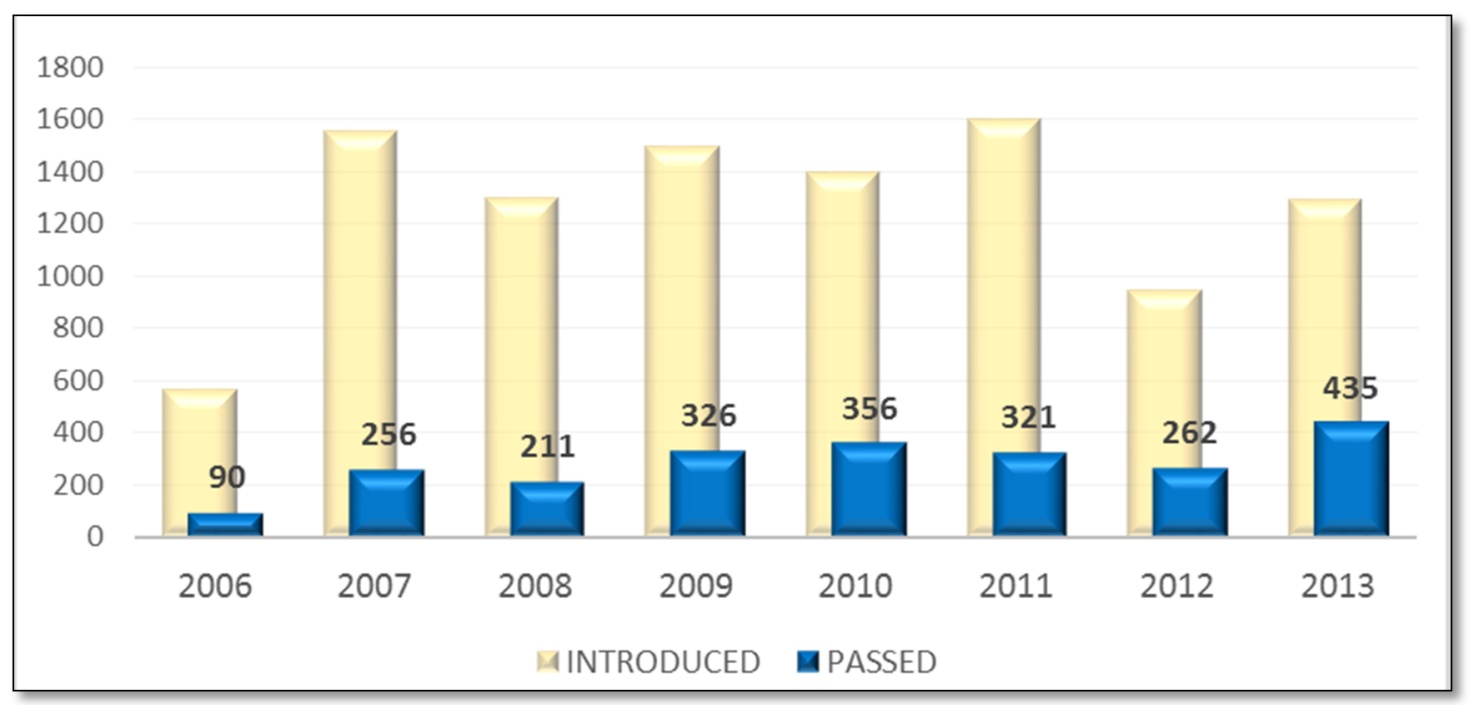

Figure 1. Annual state activity: immigration bills introduced and passed. Source: National Conference of State Legislatures. 
Congressional reform efforts in Congress failed in 2006 and again in 2007, and from 2006-2008 there is an observable uptick in legislative output from the states. In successive years, the total would climb, with greater movement in 2009 and 2010 - years in which the Congress made no indications to address immigration issues. Two thousand eleven and 2012 totals are successively lower likely due to several factors: by 2011 statehouses were engaged in redistricting for the 2012 election, parts of the 2010 Affordable Care Act took effect in 2012 and necessitated state level preparations. Also, during this period states awaited the Supreme Court's decision concerning SB 1070 in Arizona v. United States. However, by 2013, though early in the year that a bipartisan Senate committee initiated a proposal for multi-pronged policy reforms, state legislatures resumed their work.

Statehouses passed bills that attend to every major class of immigrant-unauthorized, legal permanent residents, refugees, foreign students, and temporary/seasonal foreign laborers (technically referred to as "non-immigrants"). Also notable is the range of policy areas in which immigration-related bills occurred. Tables 1 and 2 sort the 2257 bills according to policy areas, with Table 1 covering laws and Table 2 the bills that were actually nonbinding resolutions.

Table 1. Bills by policy area with resolution totals. Source: National Conference of State Legislatures.

\begin{tabular}{|c|c|c|}
\hline Policy Areas & Bill Totals by Area & Percent Resolutions \\
\hline Celebrate state's immigrant heritage & 365 & $98 \%(357)$ \\
\hline Border control \& "comprehensive reform" & 32 & $88 \%(28)$ \\
\hline Private bills, etc. & 372 & $85 \%(315)$ \\
\hline Legal services for immigrants & 30 & $63 \%(19)$ \\
\hline Education & 161 & $13 \%(21)$ \\
\hline Employment & 200 & $13 \%(25)$ \\
\hline Law enforcement & 225 & $11 \%(24)$ \\
\hline Omnibus bills & 19 & $11 \%(2)$ \\
\hline Human trafficking & 97 & $10 \%(10)$ \\
\hline Health \& health care & 121 & $10 \%(12)$ \\
\hline Public benefits & 137 & $9 \%(13)$ \\
\hline Voting and elections & 32 & $9 \%(3)$ \\
\hline ID/Driver's licenses, other licenses & 299 & $7 \%(20)$ \\
\hline State budgets/appropriations relating to immigration or related agencies & 167 & $1 \%(2)$ \\
\hline
\end{tabular}

Of the 2257 bills, 851 (nearly 38 percent of the total) were resolutions-reflecting symbolic legislative efforts. As Table 1 shows, the use of resolutions tended to occur with greater frequency in specific policy areas. Many states - even the states of Georgia, South Carolina, Alabama for example, that otherwise passed extremely strict, anti-immigrant laws during this period - contributed to the passage of 359 resolutions recognizing contributions of different immigrant groups to their state's character or its development. These range from numerous state declarations of March as "Irish American Heritage Month", to Illinois's memorialization of the 100th anniversary of the Cherry Mine disaster which claimed immigrant lives. Some of these resolutions praised organizations serving immigrant communities. Similarly, the private resolutions (315 in total) involved honors for individual immigrants or community and/or religious leaders who had served immigrant communities. 
Table 2. State laws by policy area. Source: National Conference of State Legislatures.

\begin{tabular}{|c|c|c|}
\hline & Policy Area & No. Laws \\
\hline 1. & ID/driver's licenses/other licenses & 279 \\
\hline 2. & Law enforcement & 201 \\
\hline 3. & Employment & 175 \\
\hline 4. & State budgets/appropriations relating to immigration or related agencies & 165 \\
\hline 5. & Education & 140 \\
\hline 6. & Public benefits & 124 \\
\hline 7. & Health \& health care & 109 \\
\hline 8. & Human trafficking & 87 \\
\hline 9. & Private bills, etc. & 57 \\
\hline 10. & Voting and elections & 29 \\
\hline 11. & Omnibus bills & 17 \\
\hline 12. & Legal services/assistance & 11 \\
\hline 13. & Celebrate state's immigrant heritage & 8 \\
\hline 14. & Border control & 4 \\
\hline & Total Laws & 1406 \\
\hline
\end{tabular}

Resolutions also formalize a state's stance on immigration and related issues, and they can include requests to Congress and the President; such bills provide a mode of address to the federal government that is official and public (if primarily symbolic) for issues over which states have no authority. The border control resolutions, for example, called on Congress and the President to secure the border or, in the case of New Mexico (HM 50, 2008) asked for funding and personnel to repair fencing. Texas resolutions (SCR 10, in 2009 and HCR 80, in 2013) requested that Congress investigate inefficiencies in border crossings and their effects on commerce with Mexico. Georgia and Louisiana resolutions preemptively rejected any congressional plans to legalize unauthorized immigrants and/or ordered their state's national delegation not to support such measures.

In policy areas of heaviest activity like ID/driver's licenses, enforcement and employment, laws were more dominant than resolutions. In these cases (as was the case as well for public benefits, education and health/health care), resolutions were typically promises (without funding) to create task forces to study aspects of that area. A typical example would be a Hawai'i's 2007 directive to the state's Department of Human Services to study the state's immigrants who have been victims of trafficking, or several states' pledges to develop studies related to educational or health concerns associated with immigrant communities.

Returning though, to the fact that the top areas for state activity produced laws and not symbolic overtures, Table 2 presents the 1406 laws sorted by policy area, which in turn shows the areas of greatest activity.

The top three areas of lawmaking vary in terms of the degree of authority states can claim. States exercise primary authority over identification, driving and professional licensing. When it comes to employment, states enjoy a considerable degree of regulatory and administrative authority, but must operate in tandem with national laws. In the area of law enforcement, states may take a supportive or cooperative part in the execution of a national goals. Since the interplay of nation and state in law 
enforcement and employment driver's licenses have also sourced jurisdictional conflicts the next sections will elaborate on state activity within the national policy scheme.

\subsubsection{Identification and Licensing}

Drivers' licenses, identification, and other licensing comprised the single area of greatest frequency. Some of the bills set standards for professional, business and recreational licensing. However, numerous state bills also addressed the 2005 REAL ID Act with laws and resolutions seeking to avoid, or grandstand against federal efforts to standardize the states' drivers' licenses and personal IDs.

Congress passed the REAL ID Act in response to the 9/11 Commission. Although national identification had previously been contentious, Congress allocated limited debate upon REAL ID's introduction, and attached the measure to an emergency appropriations bill to fund the Iraq and Afghanistan wars [63]. The Act targeted weaknesses in the states' licensing practices - such as easy counterfeiting and multiple issuance - that the 9/11 hijacker exploited. REAL ID mandated improved security with inclusion of biometrics and other machine-readable information. The law required all non-citizen applicants for licenses or state identification cards to provide documentation of lawful presence in the United States, and required states to use the Department of Homeland Security's Systematic Alien Verification of Entitlement (SAVE) database to test document authenticity and prevent unofficial immigrants from obtaining identifiers.

REAL ID has resulted in state-driven backlash, and the chief complaint is against the cost of reconfiguring state DMV's to achieve federal design requirements [37]. REAL ID resistance took both substantive and symbolic forms. Table 3 subdivides the 300 bills assigned to the "driver's license/ID/other license" category. The column on the right references professional and business licensing requirements and fee schedules - subcategories over which states have unimpeded authority. The left-hand column, by contrast, contains a tally of laws whose contents reflect state responses to federal REAL ID.

Table 3. State ID/drivers and other licensing bills, 2006-2013.

\begin{tabular}{lclll}
\hline \multicolumn{1}{c}{ ID/Driver's License Bills } & \multicolumn{3}{c}{ Other State License Bills } \\
\hline Allows ID/ Driver's irrespective of immigration status & 8 & Professional Licensing & 63 \\
ID theft/fraud & 16 & Other Requirements (fees, expiration dates) & 49 \\
Anti-REAL ID & 28 & Gun permits/licensing & 34 \\
Regulations Consistent with REAL ID & 51 & Regulatory Business/Operating & 32 \\
& & Recreational licensing (hunting, fishing, etc.) & 16 \\
& & Birth certificates (overseas adoptions) & 3 \\
Subtotal & 103 & Subtotal & 197 \\
\hline
\end{tabular}

Source: National Conference of State Legislatures.

Eight laws are "expansive" in specifying that immigration status is not a prerequisite for attaining a driver's license; Vermont, Colorado, Connecticut, California, Illinois, each passed its own version with its own regulations in 2013. Laws pertaining to ID Theft/Fraud penalized use of falsified documents in any official capacity or to secure employment - measures aimed at undocumented immigrants. Twenty eight bills (fifteen laws and thirteen resolutions) were "Anti-REAL ID" in their rejection of federal guidelines. These took various forms: the South Carolina legislature, for example, directed the governor 
not to implement any aspect of REAL ID (H 4823, 2008); other states gave similar orders to their DMV heads (e.g., Louisiana's HB 715, 2008 or Alaska's SB 202, 2008). Other states refused to REAL ID oriented appropriations for DMVs. The resolutions commanded Congress to repeal the law.

The subcategory, "Regulations consistent with REAL ID" however, offers a twist to this tale of state rebellion. Fifty one state laws made acquisition of licenses and ID's more difficult by limiting which documents legal immigrants could supply for their applications, or required even lawful immigrants to renew in person instead of online. Other states appropriated money for enhanced cards with anti-counterfeiting features.

\subsubsection{Law Enforcement}

The area of immigration law enforcement has transformed from a system in which national agencies once practiced near exclusive authority, to a system that engages lower-level agencies to accomplish national goals. Congressional policy and federal agency initiatives from DHS, ICE and DOJ, engage with state and local law to assist in status checks and detention of immigrants. The 1996 Anti-Terrorism and Effective Death Penalty Act facilitated interagency information-sharing, a practice that would accelerate after the 11 September 2001 terror attacks. The 1996 Illegal Immigration Reform and Immigrant Responsibility Act's section 287(g) permitted state and local police to enter into formal agreements with the Department of Justice (later the DHS) to assist in the apprehension and detention of unauthorized immigrants in areas beyond the reach of national immigration enforcement agencies. In 2002, Florida became the first participant; by 2012 a total of 19 states had units involved (U.S. Department of Homeland Security. Office of the Inspector General 2013).

With the roll-out of the ICE initiative, Secure Communities in 2008 (a program designed to "to identify and remove aliens who pose a threat to public safety"), the framework for extension of federal reach into states, counties and municipalities effectively blurred pre-existing lines of authority for the purposes of interior enforcement. The strategy was to focus on apprehension and removal of unauthorized immigrants who had committed aggravated or violent felonies and thus allow ICE to prosecute people in violation of immigration laws when state and/or local authorities caught immigrants violating criminal laws. In practice the DHS's own Task Force on Secure Communities noted confusion, misinformation, and abuse of program responsibilities. Participating local authorities would entrap unauthorized immigrants whose offenses were technically minor violations (traffic infractions, for example) not level 1 felonies (Homeland Security Advisory Council 2011). In December, 2012 ICE announced that it would no longer renew 287(g) agreements (U.S. Immigration and Customs Enforcement 2012) ${ }^{6}$.

The national context matters for this policy area because state and local engagement in enforcement was voluntary. Thus bills in the "law enforcement" category predominantly represent state efforts to cooperate with federal efforts, as summarized in Table 4.

6 Human trafficking laws appeared 97 times, and the content of these bills typically brought aspects of state law enforcement in concert with the national Victims of Trafficking and Violence Protection Act of 2000, which aims to combat trafficking and shield victims and witnesses from prosecution. 
Table 4. Summary of state immigration enforcement laws, 2006-2013.

\begin{tabular}{|c|c|c|c|c|c|c|c|c|}
\hline Type of Immigration Enforcement Law & 2006 & 2007 & 2008 & 2009 & 2010 & 2011 & 2012 & 2013 \\
\hline $\begin{array}{l}\text { 1. Appropriations for enforcement-related } \\
\text { programs and agencies... }\end{array}$ & $\mathrm{NJ}$ & $\begin{array}{l}\mathrm{AZ}(2)^{*} \mathrm{MI} \\
\mathrm{NY}, \mathrm{TN}(2)\end{array}$ & MS & $\mathrm{AZ}(2)$ & $\mathrm{AZ}$ & $\mathrm{SC}$ & & \\
\hline $\begin{array}{l}\text { 2. Directives for detaining, sentencing, or } \\
\text { incarcerating criminal suspects, defendants, } \\
\text { or witnesses who are suspected/discovered } \\
\text { to be illegal aliens... }\end{array}$ & $\begin{array}{l}\mathrm{GA}^{* *}, \mathrm{OH}, \\
\mathrm{IL}(2), \mathrm{VA}\end{array}$ & $\begin{array}{l}\mathrm{AZ}(2) \\
\mathrm{AZ} \mathrm{CO}\end{array}$ & $\begin{array}{l}\text { AL, GA, } \\
\text { IL, VA }\end{array}$ & & $\mathrm{CA}, \mathrm{LA}, \mathrm{SC}$ & $\begin{array}{l}\mathrm{AZ}(3), \\
\mathrm{CA}(2,1 \\
\text { vetoed }) \\
\mathrm{CO}, \mathrm{TX}\end{array}$ & $\mathrm{DE}$ & $\mathrm{OK}$ \\
\hline $\begin{array}{l}\text { 3. Allow transfer of custody of illegal and/or } \\
\text { criminal aliens to federal authorities... }\end{array}$ & $\mathrm{OH}$ & NY, IL, TX & $\mathrm{NC}$ & $\mathrm{AR}, \mathrm{NH}, \mathrm{OK}$ & $\mathrm{AZ}$ & WA & DC, IL, PA & \\
\hline $\begin{array}{l}\text { 4. Mandate checks on immigration status of } \\
\text { individuals detained for felony or drunk } \\
\text { driving charge... }\end{array}$ & $\mathrm{GA}, \mathrm{OH}$ & $\mathrm{NC}$ & GA, VA & $\mathrm{AZ}, \mathrm{LA}, \mathrm{OK}$ & & & & \\
\hline $\begin{array}{l}\text { 5. Mandate state agencies to cooperate with } \\
\text { federal immigration law enforcement } \\
\text { (includes directives for information- } \\
\text { sharing)... }\end{array}$ & $\mathrm{CO}, \mathrm{GA}, \mathrm{OH}$ & $\mathrm{OK}, \mathrm{TN}$ & $\mathrm{CO}$ & $\begin{array}{l}\text { CA (vetoed) } \\
\text { TN, UT }\end{array}$ & GA, VA & $\begin{array}{c}\text { AZ, } \\
\text { MN (vetoed) } \\
\text { TX, VA }\end{array}$ & & $\mathrm{AL}$ \\
\hline $\begin{array}{l}\text { 6. Defines act of "harboring" unlawful } \\
\text { immigrants as a crime in state code... }\end{array}$ & GA & & & & $\mathrm{AZ}, \mathrm{OK}$ & MT (vetoed) & IN & \\
\hline $\begin{array}{l}\text { 7. Directives regarding immigrants who are } \\
\text { convicted sex offenders... }\end{array}$ & $\mathrm{CO}, \mathrm{SD}$ & $\mathrm{ME}, \mathrm{OK}, \mathrm{TN}$ & $\begin{array}{l}\text { CA, HI, UT, } \\
\text { TN, CA }\end{array}$ & $\begin{array}{l}\text { IA, TN, } \\
\text { UT, AL }\end{array}$ & $\begin{array}{l}\mathrm{AL}, \mathrm{CT}, \mathrm{UT} \\
\mathrm{MD}, \mathrm{TN}, \mathrm{KS}\end{array}$ & $\begin{array}{l}\text { CA, ND, } \\
\text { CT, UT, MI, } \\
\text { MS, NM, } \\
\text { OK, SD }\end{array}$ & KS, ME, UT & $\mathrm{CO}, \mathrm{MI}, \mathrm{NM}$, \\
\hline $\begin{array}{l}\text { 8. Limit use of restraints on pregnant women } \\
\text { in custody (includes women held in custody } \\
\text { for immigration violations)... }\end{array}$ & & & & & PA & & DE, FL, LA & \\
\hline 9. Officers must be U.S. citizens... & & & & & $\mathrm{OK}$ & & & $\mathrm{TX}$ \\
\hline
\end{tabular}

Source: National Conference of State Legislatures, author-coded; "Numbers in parentheses indicate passage of more than one bill for that year in that subcategory; ${ }^{* *}$ Georgia's SB 529 (2006) and Ohio's SB 9 (2006) were omnibus bill coving several enforcement areas, which is why they appear more than once. 
Among the examples are appropriations for immigration enforcement, promises to surrender individuals found in violation of immigration laws to federal officials, directives to lower agencies to check the immigration status of anyone who winds up in police custody, pledges to lobby DHS for funding should circumstances warrant, and mandates that all or some state agencies outside of criminal justice cooperate with law enforcement efforts.

\subsubsection{Employment Laws}

States are expected to operate within a federal regulatory framework that designates which immigrants are authorized to work, how they may prove work eligibility, and that designates penalties for employment violations. In 1996 the federal government tested an automated employment verification system, (first called Basic Pilot, then re-named E-Verify), and encouraged, but did not mandate its use in states. As Table 5 shows, much of the regulatory content of the employment laws passed from 2006-2013 involves states mandating use of E-Verify among different classes of employers (such as those receiving public contracts in Pennsylvania, Oklahoma and Missouri, among other states). Nineteen states currently mandate some use of the program; Arizona, Utah, Alabama, Georgia and Mississippi have the broadest mandates and strictest penalties. Other state bills do not mandate E-Verify, but do demand that employers establish work eligibility.

The 1986 IRCA forms the basis of federal regulation of work eligibility and punishment for employers, but when the 2007 Legal Arizona Worker's Act (LAWA) punished hiring outside the new law with confiscation of business licenses, the tougher state penalty (and a similar one in Oklahoma) was challenged for exceeding national law. The Court's decision to uphold LAWA in Chamber of Commerce v. Whiting (2011), opened the door for other states to use work eligibility and workplace participation enforcement as an alternate route to immigration enforcement.

Table 5. Types of state employment laws, 2006-2013.

\begin{tabular}{|c|c|c|c|c|c|c|c|c|}
\hline Type of Employment Law & 2006 & 2007 & 2008 & 2009 & 2010 & 2011 & 2012 & 2013 \\
\hline $\begin{array}{l}\text { 1. Mandates BasicPilot/e- } \\
\text { Verify...* }\end{array}$ & $\begin{array}{l}\mathrm{CO}, \mathrm{PA}, \\
\mathrm{TN}, \mathrm{GA}\end{array}$ & $\begin{array}{l}\text { AZ, GA, } \\
\text { IA, MI, } \\
\text { TN, CO, } \\
\text { GA, OKT, } \\
\text { PA }\end{array}$ & $\begin{array}{c}\mathrm{CO}, \mathrm{ID}, \mathrm{AZ} \\
\mathrm{MS}, \mathrm{AZ} \\
\mathrm{SC} * \mathrm{UT}\end{array}$ & & $\begin{array}{c}\text { GA, } \\
\text { UT, VA }\end{array}$ & $\begin{array}{l}\text { LA, TN, } \\
\text { VA (2) }\end{array}$ & $\begin{array}{l}\text { LA, } \\
\text { PA, } \\
\text { WV }\end{array}$ & $\begin{array}{l}\text { GA, } \\
\mathrm{MO}\end{array}$ \\
\hline $\begin{array}{l}\text { 2. Verification of work } \\
\text { eligibility (without mandate } \\
\text { for Basic Pilot/E-Verify)... }\end{array}$ & & $\begin{array}{l}\text { TX, HI, } \\
\text { IA, WV }\end{array}$ & $\begin{array}{l}\text { VA (3), } \\
\text { TN, WV }\end{array}$ & IL, UT & $\begin{array}{c}\mathrm{FL}, \\
\mathrm{NE}(2)\end{array}$ & $\mathrm{NC}$ & & \\
\hline $\begin{array}{l}\text { 3. Workplace regulation, } \\
\text { employment taxes, civil } \\
\text { rights protections... }\end{array}$ & $\begin{array}{l}\text { ID, WA, } \\
\text { GA }\end{array}$ & $\begin{array}{l}\mathrm{AR}, \mathrm{AZ} \\
\mathrm{GA}, \mathrm{IL}\end{array}$ & $\mathrm{AZ}, \mathrm{CO}, \mathrm{FL}$ & & $\begin{array}{c}\mathrm{CA}, \mathrm{IA}, \\
\mathrm{SC}, \\
\mathrm{VA}, \mathrm{WA}\end{array}$ & CA, UT, VA & $\begin{array}{l}\mathrm{CT} \\
\mathrm{CA}\end{array}$ & \\
\hline $\begin{array}{l}\text { 4. Proof of legal status } \\
\text { required to collect } \\
\text { unemployment insurance or } \\
\text { workman's compensation.... }\end{array}$ & $\begin{array}{c}\text { ID, KS, } \\
\text { WA }\end{array}$ & $\begin{array}{c}\mathrm{HI}, \mathrm{CO}, \\
\mathrm{IL}, \mathrm{KS}, \\
\mathrm{LA}, \mathrm{MN}, \\
\mathrm{MS}, \mathrm{MT}, \\
\mathrm{NM}, \mathrm{OR}, \\
\mathrm{UT}, \mathrm{ME}\end{array}$ & $\mathrm{AK}$ & & & & & \\
\hline
\end{tabular}


Table 5. Cont.

\begin{tabular}{|c|c|c|c|c|c|c|c|c|}
\hline Type of Employment Law & 2006 & 2007 & 2008 & 2009 & 2010 & 2011 & 2012 & 2013 \\
\hline $\begin{array}{l}\text { 5. Penalties for employer } \\
\text { violations of state eligibility } \\
\text { laws... }\end{array}$ & $\begin{array}{l}\mathrm{LA}, \\
\mathrm{GA}, \mathrm{CO}\end{array}$ & $\begin{array}{l}\mathrm{AZ}, \mathrm{TN}, \\
\mathrm{WV}, \mathrm{OK}^{\mathrm{b}}\end{array}$ & $\begin{array}{l}\mathrm{AZ}, \mathrm{CO}, \\
\mathrm{MD}, \mathrm{MO}, \\
\mathrm{MS}, \mathrm{VA}\end{array}$ & HI, TN & $\begin{array}{l}\text { HI, KS, } \\
\text { ME, WV, } \\
\text { WI }\end{array}$ & LA & $\begin{array}{c}\text { MA, } \\
\text { VA, TN }\end{array}$ & \\
\hline $\begin{array}{l}\text { 6. Penalties for immigrants } \\
\text { falsifying work eligibility... }\end{array}$ & & & & $\mathrm{TN}(2)$ & & ID & $\mathrm{NH}$ & \\
\hline $\begin{array}{l}\text { 7. Restricts unemployment } \\
\text { and/or workman's comp, } \\
\text { job training based on } \\
\text { legal status... }\end{array}$ & & & & $\begin{array}{l}\mathrm{MN}, \\
\mathrm{IA}, \mathrm{IL}\end{array}$ & $\begin{array}{l}\text { MS, } \\
\text { NE, OK }\end{array}$ & $\begin{array}{c}\text { MI, MIS, } \\
\text { MO, NJ } \\
\text { (vetoed), } \\
\text { OR, UT, } \\
\text { WA }\end{array}$ & $\mathrm{AL}$ & $\mathrm{TN}$ \\
\hline $\begin{array}{l}\text { 8. State limits or bans } \\
\text { employer participation in } \\
\text { BasicPilot/ E-Verify }\end{array}$ & & IL (Ban) & & & & $\begin{array}{c}\text { CA } \\
\text { (Bans } \\
\text { unless } \\
\text { federal } \\
\text { funding at } \\
\text { stake) } \\
\end{array}$ & & \\
\hline
\end{tabular}

* States vary in classes of employers that require use of Basic Pilot/ E-Verify. States appearing across several years expanded the classes of employers required to participate.

\subsubsection{Other Policy Areas}

After the top three categories, other state bills fell into policy areas that fall primarily to the states, like education, or that depend on states for service delivery such as public benefits (which includes programs such as Temporary Aid to Needy Families (TANF) that was devolved to the states to manage in 1996) and health-related bills (many of these prior to the passage of ACA named unlawful immigrants as an excluded class from state coverage or included them).

The rules of voting and elections encompass another area almost entirely under state purview ${ }^{7}$, the thirty two state laws in this field primarily defined voter eligibility to include only citizens, and itemized acceptable documentation for proof of citizenship/voter eligibility (examples from 2011 are Alabama and Georgia, in 2012 Kansas and Utah, in 2013 and Virginia, with states like Colorado and New Hampshire passing bills that updated or reconfirmed existing voter eligibility bills). In 2013 Virginia passed an addition law requiring that the state Board of Elections register with and cross-check registrants against the SAVE (Systematic Alien Verification for Entitlements) database to prove voter eligibility.

7 Voting rights are protected by federal legislation (the Voting Rights Act of 1965 and its extensions and renewals through 2007) and enforced via the Justice Department. Although states are in charge of redistricting for purposes of congressional reapportionment, when a state's electoral maps are criticized for impinging on voting rights, these can land in the Justice Department or even the federal court. 


\subsection{Immigration Federalism 2006-2013: A Reassessment}

The contents of bills from the top three categories shows state lawmaking in service of federal programs that encourage state involvement, or legislation that reiterates nationally-defined goals. Even the hostile state response to REAL ID did not preclude measures among states to tighten access to identifiers - which is a goal of the federal law.

In the area of state immigration enforcement laws, it is clear that federal policies put in place prior to the explosion in state enforcement laws (such as the 1995 ATEDPA and 1996 IIRAIRA) created channels for state involvement, because state laws have an iterative quality to them: they cite federal laws and agencies, and they identify their role as falling within federally-defined guidelines. State laws that reach beyond these, like Arizona's SB 1070 and Alabama's SB 56, still identified existing federal law as justification for their existence. Congressional policy would guard against the Court's rejection of SB 1070s most controversial section, 2b. In the less delimited area of employment laws, states enjoy broad parameters for action, even when (as was true for the Whiting decision concerning the 2007 LAWA and 2007 Oklahoma omnibus provisions) state regulations and penalties exceed those provided for in federal law [62]. Referring back to Table 5, states have also utilized this space to restrict employment-related benefits via immigration status checks, they have instituted penalties for unauthorized workers. But, some states have also expanded protections for unauthorized immigrant workers: California's 2012 law extended civil rights protections to domestic workers, and Iowa, Virginia and Washington each redefined "work" to include services performed by unauthorized alien workers.

While the top three areas of state immigration lawmaking (ID/driver's licenses/other licenses, law enforcement, and employment) suggest most states are crafting policies aimed toward the restriction of unauthorized immigrants, some states are pursuing accommodation in ways that clash with national goals. Such actions are most visible in state laws addressing higher education and identification access for unauthorized immigrants. The following two sections present sources of challenges to federal policy.

\subsubsection{Higher Education Access for Undocumented Immigrants}

The Development, Relief, and Education for Alien Minors proposal (commonly referred to as the DREAM Act), a proposal to allow young, unauthorized immigrants who are enrolled in post-secondary education or military service an opportunity to legalize, has languished in Congress despite reintroduction and continued consideration. Some states have moved to either open their post-secondary institutions and/or facilitate access by charging in-state tuition (typically much lower than that charged to foreign students or out-of-state residents) and have done so by making residency (rather than legal status) the mechanism for claiming the benefit. States pursuing such measures run the risk of violating federal law: Section 505 of the federal 1996 IIRIRA prohibits states from allowing undocumented immigrants access to their colleges and universities, and non-compliance could lead to loss of federal funds [64].

Nonetheless, seventeen states offer some form of access for students who are otherwise undocumented, as illustrated in Figure 2. 


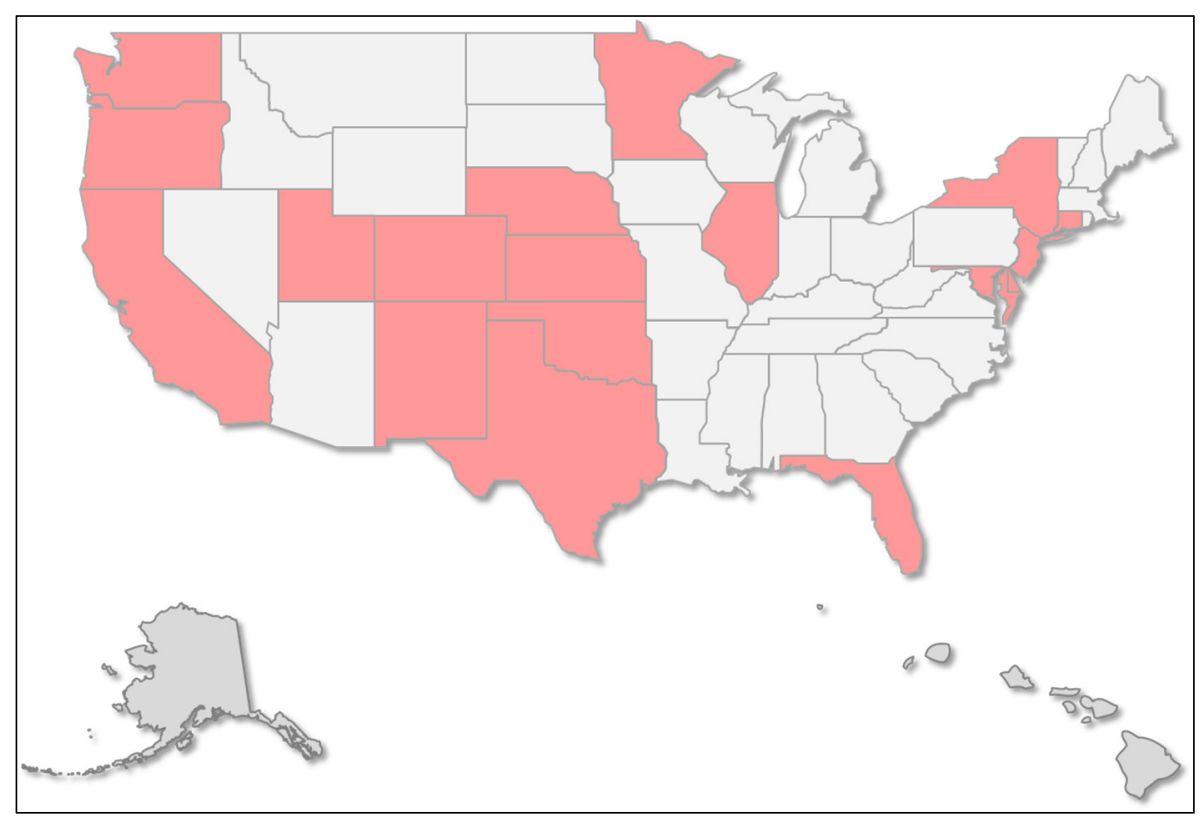

Figure 2. States extending in-state tuition to unauthorized immigrants by 2013.

These states admit immigrants who graduated from that state's primary and secondary schools to pay in-state tuition regardless of legal status. Even if it were to pass, the DREAM Act does not contain an in-state tuition mandate: states would retain the authority to make those determinations. The seventeen states listed above might be considered as most reflective of state-level independence since most passed their laws prior to the Obama administration's executive action, known as DACA, or Deferred Action for Childhood Arrivals in August 2012. Motivated in part by congressional stalemate on minors who have lived in the U.S. most of their lives and, who are broadly considered most deserving of relief, DACA lifted the specter of deportation for 1.2 million young people. Even after DACA, however, education access laws remain significant for that population: recent research shows approximately fifty five percent of those eligible for DACA applied, with individuals enrolled in secondary and post-secondary educational institutions most likely to seek DACA [65].

\subsubsection{Driver's Licenses and State-Issued Personal Identifiers}

In 2013, eight states passed laws that would extend the availability of driver's licenses and/or personal identifiers to individuals based on proof of residency. As Figure 3 shows, prior to 2013, only two states, Washington and Utah, offered licenses to people unable to prove lawful immigration status.

Significantly, California was among the states expanding access in 2013, and its size ensured that its decision reverberated nationally. The California license is a "marked" card, meaning that it clearly specifies that it is not a valid form of national identification. While the markings signal that the card does not offer proof of certification of legal status, AB 60 also included anti-discrimination provisions to protect carriers of the redesigned card. The statute also "explicitly prohibits using the license for criminal investigation, or arrest based on immigration status" [66]. These provisions stand in contrast to the federally-encouraged and state-copied trends toward inter-agency information sharing for enforcement and immigration purposes featured in many state enforcement and employment eligibility laws. 


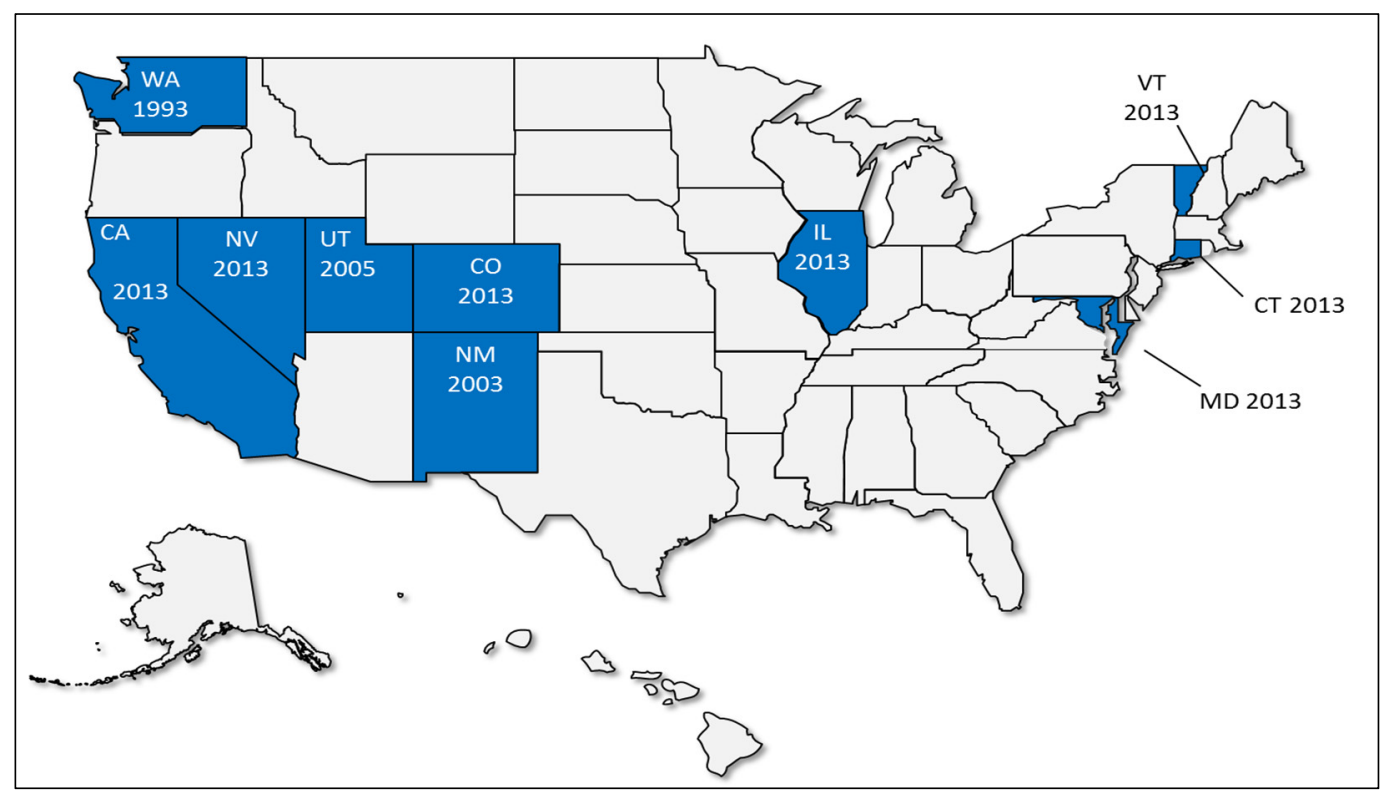

Figure 3. States offering driver's licenses or permits for unauthorized immigrants by 2013.

There is some variation among the state systems to expand eligibility for licenses. Like California, Colorado, Connecticut and Maryland, have deployed a "two-tiered" license system that allows their DMVs to issue REAL ID-compliant cards for eligible individuals who can supply necessary documentation. For recipients of second-tier cards, disclaimers such as "Not valid for federal identification, voting, or public benefits purposes", (Colorado) feature prominently, and some cards denote validity only for the purposes of driving within those states. Utah, Nevada and Illinois policies are more limited: these states offer proof of driving "authorization" or "privilege" that is both narrowly useful and that is temporary: Utah's, for example, expires in a year. These driver authorization laws do not extend to non-driving identifiers as in California and Colorado.

Earlier, the survey of state laws in the subcategories of driver's licenses and identifiers showed most states moving toward stricter application requirements, including steeper penalties for misrepresentation and/or presentation of false documentation for personal employment or professional engagement, as well as to secure state documents. All of these measures are restrictions targeting unofficial immigrants, whose status is a matter of federal law. By contrast, California, Colorado, Connecticut and other states have taken steps as subnational governments to formalize and legitimate people occupying their spaces who exist outside the boundaries of federal law.

\section{Discussion}

"The bill I'm about to sign into law-Senate Bill 1070 — represents another tool for our state to use as we work to solve a crisis we did not create and the federal government has refused to fix the crisis caused by illegal immigration and Arizona's porous border".

—Arizona Governor Jan Brewer, 2010 [67]

"When a million people without their documents drive legally and with respect in the state of California, the rest of this country will have to stand up and take notice". 
Immigration is a subject that lends itself to symbolic politicking [69], and there has been quite a bit of political posturing by state governors and legislators who claim that their states are forced to legislate immigration in the wake of failed federal efforts. This is not to say that state legislative activity has little substantive or practical impact - to the contrary, as the 2006-2013 legislative analysis demonstrates, immigrants of all conceivable statuses are facing confusing and irregular statutory arrangements that shift from state to state. In the case of law enforcement, there are even differences within states as cities pursue their own agendas [15]. However, state lawmaking that tests federal authority also engages with a symbolic politics of federalism. Murray Edelman, who conceived of the role of symbolism in structuring politics, saw value in condensation symbols which provoke threat or provide reassurance particularly on issues with high saliency or controversy ([41], p. 7). State-level policy activism reassures the public that someone is attending to immigration matters even if Washington DC is not. From this perspective, if a state law faces court challenges or is struck down, these outcomes do not negate that governors and/or legislatures are trying to craft solutions, and that they are doing so further amplifies the absence of congressional action.

The two statements above, each from governors presiding over states with contrasting approaches to unauthorized immigrants, capture this communicative facet of state-level lawmaking; each governor's statement positions their state within a broader, national debate about what should be done for the resident unauthorized population. Each reflects on state law as substantive accomplishment. Significantly, however, national laws governing each of these areas do exist and federal actions may negate the operationalization if not the statutory components of either measure. The conflict identified in Governor Brewer's statement conceals the manner in which national law enforcement has penetrated states and localities at their invitation, and with their cooperation. In the case of state driver's licenses and IDs, areas in which the federal government mandates REAL ID compliant identifiers for access are growing increasingly constricted, and, correspondingly, starting January of 2016, residents of states not in compliance with federal standards will not be able to board even domestic flights [70]. While Governor Brown is correct that his state's statute will facilitate the regulatory aspects of driving and may bring a measure of respect and ease of burden on the undocumented population, the fact remains that this policy solution with national ramifications remains narrowly limited to his geographic jurisdiction. Freedom of movement within the U.S. - a significant if underappreciated liberty — will still only be enjoyed by those with nationally-defined status.

Moreover, just as mobilization occurs to push certain policies, immigration hard-liners have also mobilized against driver's license extensions. New Mexico's Republican governor, Maria Martinez, has attempted to have that state's driving privileges repealed, and the GOP in Colorado has endeavored to halt implementation of that state's more recent driver's license law [71]. Recipients of the 2012 Deferred Action for Childhood Arrivals (DACA) who are supposed to be able to work and drive as per executive action, were denied driver's licenses in Arizona and Nebraska until the 9th Circuit ordered Arizona's compliance with federal law in 2014 and the Nebraska state legislature revised their law and even overrode the governor's veto in 2015. In the latter case, legislators revised the state statute in accordance with federal REAL ID law which makes DACA recipients an eligible class for state licenses [72].

Whether states opt to involve immigrants based on fact of residency or whether they decide to restrict by aligning their definitions of membership with those provided for in federal law, the federal system, particularly in its present form of intertwined responsibilities, provides the mechanisms for states to do 
so. However, as a governance ideology that legitimates states that solve immigration problems in their own way, these symbolic appeals to states as pragmatic problem-solvers that fulfil a positive role in the American policy system, obscures the rise of a multi-layered enforcement system, and the persistence of ill-defined and uneven civil rights protections that now characterize our immigration regime.

\section{Conclusions}

The fact that state immigration policies are framed as intergovernmental conflicts is not new-in fact, federal absence from the area of immigration is a recurring motif in national and subnational immigration conflicts. What this article stresses, however, is that symbolic federalism - which provides an ideological backing to state involvement in an area where the federal government has long dominated and continues to constrain, shape, and define possibilities for state involvement. In its current form, symbolic federalism has distinguishable features. One of its forms, fiscal conservatism, locates states' problems in immigrant consumption of public benefits. Calavita (1996) recognized this when she identified California's Proposition 187 as a symbolic policy whose passage captured public anger and discontent with welfare state retrenchment and refocused those anxieties on immigrants. Years afterwards - and apart from California's political and policy pivot away from 187-other states have followed suit. This outcome was not inevitable, but it was enabled with federal statutes encouraged with federal enforcement agencies seeking subnational modes by which to expand their interior reach.

A second form of symbolic federalism depends on federal-state conflict to showcase state autonomy and policy pragmatism historically associated with both conservative and progressive state approaches to social problems [16]. This analysis considered the recent surge in state immigration lawmaking through the lens of symbolic federalism in an effort to shed light on the politics of state-driven lawmaking. This symbolic aspect of American federalism justifies both conservative and progressive calls to devolve policy away from the national government. Its framework promotes states as a pragmatic alternatives to congressional gridlock. Future inquiries into state and local laws should also account for how state immigration activism engages with this evocative politics, and it, in turn, shapes the terrain upon which these policy battles are fought.

\section{Conflicts of Interest}

The author declares no conflict of interest.

\section{References and Notes}

1. Feldman, Paul. "Anti-Illegal Immigration Prop. 187 Keeps 2-To-1 Edge.” Los Angeles Times, 15 October 1994. Available online: http://articles.latimes.com/1994-10-15/news/mn-50380_1_illegalimmigrants (accessed on 2 October 2015).

2. Feldman, Paul. "Support for Prop. 187 Erodes, but It still Leads.” Los Angeles Times, 15 October 1994. Available online: http://articles.latimes.com/1994-10-27/news/mn-55339_1_times-poll (accessed on 2 October 2015). 
3. Kalia, Kirin. "Top 10 of 2007-Issue \#7: U.S. Cities Face Legal Challenges, and All 50 States Try Their Hand at Making Immigration-Related Laws." In Migration Information Source: The Online Journal of the Migration Policy Institute. Washington: Migration Policy Institute, 2007.

4. National Conference of State Legislatures. Available online: www.ncsl.org (accessed on 15 August 2015).

5. Motomura, Hiroshi. "Federalism, International Human Rights, and Immigration Exceptionalism." University of Colorado Law Review 70 (1999): 1361-94.

6. Rodriguez, Cristina M. "The Significance of the Local in Immigration Regulation." Michigan Law Review 106 (2008): 567-642.

7. Schuck, Peter H. "Taking immigration federalism seriously." The University of Chicago Legal Forum (2007): 57-92.

8. Tichenor, Daniel J., and Alexandra Filindra. "Raising Arizona V. United States: Historical Patterns of American Immigration Federalism." Lewis and Clark Law Review 16 (2012): 1215-47.

9. Matomura, Hiroshi. "Immigration outside the Law." Columbia Law Review 108 (2010): 2037-97.

10. Olivas, Michael A. "Immigration-Related State and Local Ordinances: Preemption, Prejudice, and the Proper Role for Enforcement." The University of Chicago Legal Forum (2007): 27-56.

11. Wishnie, Michael J. "Laboratories of Bigotry? Devolution of the Immigration Power, Equal Protection, and Federalism.” New York University Law Review 76 (2001): 493-569.

12. Guttentag, Lucas. "The Forgotten Equality Norm in Immigration Preemption: Discrimination, Harassment and the Civil Rights Act Of 1870." Duke Journal of Constitutional Law \& Public Policy 8 (2013): 1-52.

13. Roberts, Patrick S. "Dispersed Federalism as a New Regional Governance for Homeland Security." Publius: The Journal of Federalism 38 (2008): 416-13.

14. Newton, Lina. "Policy Innovation or Vertical Integration? A View of Immigration Federalism from the States." Law and Policy 34 (2012): 113-37.

15. Varsanyi, Monica W., Paul G. Lewis, Doris Marie Provine, and Scott Decker. "A Multilayered Jurisdictional Patchwork: Immigration Federalism in the United States." Law \& Policy 34 (2012): 138-58.

16. Robertson, David Brian. Federalism and the Making of America. New York and London: Taylor Francis, 2012.

17. Chavez, Jorge M., and Doris Marie Provine. "Race and the Response of State Legislatures to Unauthorized Immigrants." Annals of the American Academy of Political and Social Sciences 623 (2009): 78-92.

18. Provine, Doris Marie, and Gabriella Sanchez. "Suspecting Immigrants: Exploring Links between Racialised Anxieties and Expanded Police Powers in Arizona." Policing \& Society 21 (2011): 468-79.

19. Ramakrishnan, S. Karthick, and Tom Wong. Immigration Policies Go Local: The Varying Responses of Local Governments to Low-Skilled and Undocumented Immigration. Washington: Woodrow Wilson International Center for Scholars, 2008.

20. Santa Ana, Otto, and Celeste González de Bustamante, eds. Arizona Firestorm: Global Immigration Realities, National Media, and Provincial Politics. Lanham: Rowman \& Littlefield, 2012.

21. Gabriel, Trip. "Kris Kobach pushed Kansas to the Right. Now Kansas is Pushing Back." The New York Times, 16 October 2014. Available online: http:/www.nytimes.com/2014/10/17/us/politics/ 
voter-id-firebrand-kris-kobach-takes-a-low-profile-kansas-office-out-of-the-shadows.html?_r=0 (accessed on 16 October 2014).

22. Kobach, Kris W. "Reinforcing the Rule of Law: What States Can and Should Do to Reduce Illegal Immigration." In Strange Neighbors: The Role of States in Immigration Policy. Edited by Gabriel Jackson Chin and Carissa Byrne Hessick. New York: New York University Press, 2012, pp. 99-129.

23. Saslow, Eli. "Conservative Expert on Immigration Law to Pursue Suit against Executive Action." Washington Post, 22 November 2014. Available online: https:/www.washingtonpost.com/national/ 2014/11/22/f6d2b3fe-728a-11e4-ad12-3734c461 eab6_story.html (accessed on 23 November 2014).

24. Zeller, Shawn. “Alec Racks up Wins in States." CQ Weekly (2014): 84.

25. Reich, Gary, and Jay Barth. "Immigration Restriction in the States: Contesting the Boundaries of Federalism?" Publius: The Journal of Federalism 42 (2012): 422-48.

26. Boushey, Graeme, and Adam Luedtke. "Immigrants across the U.S. Federal Laboratory: Explaining State-Level Innovation in Immigration Policy.” State Politics \& Policy Quarterly 11 (2011): 390-414.

27. Spiro, Peter J. "Learning to Live with Immigration Federalism." Connecticut Law Review 29 (1997): 1627-46.

28. Archibold, Randal C. "Judge Blocks Arizona's Immigration Law." The New York Times, 28 July 2010. Available online: http://www.nytimes.com/2010/07/29/us/29arizona.html?_r=0 (accessed on 22 September 2015).

29. Lyman, Rick. "In Georgia Law, A Wide-Angle View of Immigration." The New York Times, 12 May 2006. Available online: http://www.nytimes.com/2006/05/12/us/12georgia.html?pagewanted $=$ all\&_r $=0$ (accessed on 26 September 2015).

30. Lieutenant Governor Casey Cagle. "Lt Governor Cagle: New Immigration Law Draws Line in the Sand.” States News Service, 29 June 2007. Available online: http://tgov.georgia.gov/press-releases/ 2007-06-29/lt-governor-cagle-new-immigration-law-draws-line-sand (accessed on 8 August 2008).

31. States News Service. "Gov. Blunt Signs Legislation Protecting Missouri Families, Tax Dollars from Illegal Immigration.” 8 July 2008. Available online: http://www.infozine.com/news/stories/ op/storiesView/sid/29277/ (accessed on 8 August 2008).

32. States News Service. "Gov. Sanford Calls for Passage of Immigration Reforms." States News Service, 29 May 2007.

33. Faiola, Anthony. "States' Immigrant Policies Diverge." The Washington Post, 15 October 2007. Available online: http://www.washingtonpost.com/wp-dyn/content/article/2007/10/14/ AR2007101401266.html (accessed on 8 August 2008).

34. States News Service. "Ellis Joins Nationwide Effort to Address Illegal Immigration." States News Service, 31 May 2007.

35. Wilson, Reid. "States Take Action on Immigration as Congress Stalls." The Washington Post, 21 January 2014. Available online: http://www.washingtonpost.com/blogs/govbeat/wp/2014/01/21/ states-take-action-on-immigration-as-congress-stalls/ (accessed on 21 January 2014).

36. Worden, Amy. "Pa., N.J. Join Flood of Bills on Immigrants." The Philadelphia Inquirer, 30 August 2007. Available online: http://articles.philly.com/2007-08-30/news/25230403_1_illegal-immigrantsimmigration-laws-immigration-legislation (accessed on 8 August 2008).

37. Zeller, Shawn. "Real Id Act Makes State Officials Really Angry." CQ Weekly (2006): 2354-54. 
38. Newton, Lina, and Brian E. Adams. "State Immigration Policies: Innovation, Cooperation, or Conflict?" Publius: The Journal of Federalism 39 (2009): 408-31.

39. Plotkin, Sidney, and William Scheuerman. Private Interest, Public Spending: Balanced-Budget Conservatism and the Fiscal Crisis. Boston: South End Press, 1994.

40. Calavita, Kitty. "The New Politics of Immigration: 'Balanced-Budget Conservatism' and the Symbolism of Proposition 187." Social Problems 43 (1996): 284-305.

41. Edelman, Murray Jacob. The Symbolic Uses of Politics. Urbana: University of Illinois Press, 1974.

42. King, Desmond. Making Americans: Immigration, Race and the Origins of the Diverse Democracy. Cambridge: Harvard University Press, 2000.

43. Ngai, Mae. Impossible Subjects: Illegal Immigrants and the Making of Modern America. Princeton: Princeton University Press, 2004.

44. Neuman, Gerald L. "The Lost Century of American Immigration Law (1776-1875)." Columbia Law Review 93 (1993): 1833-901.

45. Higham, John. Strangers in the Land: Patterns of American Nativism 1860-1925. New York: Atheneum, 1969.

46. The Passenger Cases, 48 U.S. (7 How) 283 (1849).

47. Henderson V. Mayor of the City of New York, 92 U.S. 259 (1875).

48. Chy Lung V. Freeman, 92 U.S. 276 (1875).

49. Calavita, Kitty. "The Paradoxes of Race, Class, Identity, and 'Passing': Enforcing the Chinese Exclusion Acts, 1882-1910." Law and Social Inquiry 25 (2000): 1-40.

50. Ngai, Mae M. "The Architecture of Race in American Immigration Law: A Reexamination of the Immigration Act of 1924.” Journal of American History 86 (1999): 67-92.

51. Smith, Rogers M. Civic Ideals. New Haven: Yale University Press, 1998.

52. Tichenor, Daniel J. Dividing Lines: The Politics of Immigration Control in America. Princeton: Princeton University Press, 2002.

53. Chae Chan Ping V. United States, 130 U.S. 581 (1889).

54. Fong Yue Ting V. United States, 149 U.S. 698 (1893).

55. Hartmann, Edward George. The Movement to Americanize the Immigrant. New York: Columbia University Press, 1948.

56. Hines V. Davidowitz, 312 U.S. 52 (1941).

57. De Canas V. Bica, 424 U.S. 351 (1976).

58. Edsall, Thomas Byrne, and Mary D. Edsall. Chain Reaction: The Impact of Race, Rights and Taxes on American Politics. New York: Norton, 1991.

59. Plyler V. Doe, 457 U.S. 202 (1982).

60. Toll V. Moreno, 458 U.S. 1 (1982).

61. Chamber of Commerce of the United States v. Edmondson U.S. Court of Appeals (2010).

62. Hessick, Carissa Byrne, and Gabriel Jackson Chin. "Introduction.” In Strange Neighbors: The Role of States in Immigration Policy. Edited by Gabriel Jackson Chin and Carissa Byrne Hessick. New York: New York University Press, 2012, pp. 1-18.

63. Regan, Priscilla M., and Christopher J. Deering. "State Opposition to Real Id." Publius: The Journal of Federalism 39 (2009): 476-505. 
64. Keller, Josh. "State Legislatures Debate Tuition for Illegal Immigrants." Chronicle of Higher Education 53 (2007): A28.

65. Batalova, Jeanne, Sarah Hooker, and Randy Capps. Daca at the Two-Year Mark: A National and State Profile of Youth Eligible and Applying for Deferred Action. Washington: Migration Policy Institute, 2014.

66. California State Assembly. Assem. Bill No. 60, 2013-2014 Reg. Sess., ch. 5242013 Cal. Stat.

67. Los Angeles Times. "Remarks by Arizona Gov. Jan Brewer, as Provided by Her Office." Los Angees Times, 23 April 2010. Available online: http://Latimesblogs.Latimes.Com/Washington/ 2010/04/Jan-Brewer-Arizona-Illegal-Immigration (accessed on 18 June 2015).

68. Office of the Governor of the State of California. "Governor Brown Signs Ab 60." 2013. Available online: http://Gov.Ca.Gov/News.Php?Id=18246 (accessed on 22 June 2015).

69. Newton, Lina. Illegal, Alien, or Immigrant: The Politics of Immigration Reform. New York: New York University Press, 2008.

70. U.S. Department of Homeland Security. "Real Id Enforcement in Brief." 2013. Available online: Http://Www.Dhs.Gov/Real-Id-Enforcement-Brief (accessed on 1 June 2015).

71. Moreno, Ivan. "Battle Looming over Colorado Immigrant Driver's Licenses." Santa Fe New Mexican, 14 October 2015. Available online: Http:/Www.Santafenewmexican.Com/News/ Local_News/Battle-Looming-Over-Colorado-Immigrant-Driver-S-Licenses/Article_68a9055d3b88-5727-Bb7a-0c9b72b28408.Html (accessed on 4 November 2015).

72. National Immigration Law Center. "DACA Access to Driver's Licenses.” 2015. Available online: Https://Www.Nilc.Org/Dacadriverslicenses2.Html (accessed on 1 October 2015).

(C) 2015 by the author; licensee MDPI, Basel, Switzerland. This article is an open access article distributed under the terms and conditions of the Creative Commons Attribution license (http://creativecommons.org/licenses/by/4.0/). 